\title{
Szkice
}

\section{Polska pamięć - dzisiaj. Co pozostaje? Trwały ślad i mechanizmy niepamiętania}

Stefan Chwin

TEKSTY DRUGIE 2016, NR 6, S. 15-29

DOI: $10.18318 /$ td.2016.6.2

C o znika (i dlaczego) z aktualnej polskiej pamięci całkowicie lub w mniejszym czy większym stopniu, a co (i dlaczego) w niej pozostaje na dłużej? Przez jakie to sita pamięci wydarzenia, daty i nazwiska z polskich dziejów przesypują się do kosza nicości? Ograniczmy się do paru dość przypadkowych przykładów. Przede wszystkim: coraz bardziej słabnie powszechna wiedza o historycznej genezie zbrodni ukraińskich na Wołyniu w 1943 roku. Wielu Polaków - i to o różnych orientacjach politycznych i światopoglądowych - nie chce pamiętać o polskich represjach na Ukrainie od XVII do XX wieku, przy równoczesnym aktywnym pamiętaniu o okrucieństwach ukraińskich, do jakich dochodziło od czasów powstania Chmielnickiego i rzezi humańskiej do rzezi na Kresach Wschodnich w latach 40. XX wieku' ${ }^{1}$. Następnie: coraz

1 Słabo pamiętana - i w prawie żadnym stopniu nie łączona w powszechnej świadomości z genezą rzezi wołyńskiej z lipca 1943 roku - jest dzisiaj pełna sprzeczności, trudna polityka ukraińska II Rzeczpospolitej: represyjne burzenie cerkwi prawosławnych na terenach zamieszkanych głównie przez ludność ukraińską (maj-lipiec 1938), aresztowania działaczy ukraińskich czy przeprowadzanie pacyfika-
Stefan Chwin - prof. zw. dr hab., historyk literatury, krytyk, pisarz. Pracuje w Katedrze Historii Literatury Instytutu Filologii Polskiej Uniwersytetu Gdańskiego. Ostatnio opublikował: Samobójstwo jako doświadczenie wyobraźni (2010), Samobójstwo $i$,grzech istnienia" (2013), Miłosz: interpretacje i świadectwa (2012), Miłosz. Gdańsk iokolice (2013), „Ein Deutsches Tagebuch" (2015). Kontakt: fposch@ug.edu.pl 
słabsza jest pamięć o polskim terroryzmie z lat 1905-1912, szczególnie zaś o pośrednim i bezpośrednim udziale w akcjach terrorystycznych tego czasu polskich kobiet z Organizacji Bojowej PPS, dokonujących m.in. skutecznych zamachów bombowych ${ }^{2}$. Kolejna sprawa: pamięta się o wymordowaniu w Katyniu ponad 10000 jeńców polskich, nie pamięta się o wymordowaniu przez polskich żołnierzy 1400 jeńców rosyjskich na rozkaz Jana Tarnowskiego, do czego doszło podczas wojny moskiewskiej w XVI wieku³. Można też z dużym prawdopodobieństwem przypuszczać, że za jakiś czas zniknie z pamięci polskiej Marzec '68, przesunięty przez dominującą "narrację narodową" do kategorii zdarzeń marginalnych i podrzędnych.

Funkcjonują tu różne sita pamięci, które odsiewają to, co warte pamiętania, od tego, co niewarte pamiętania: rodzinne, sąsiedzkie, pokoleniowe, klasowe, edukacyjne, godnościowe, polityczne, religijne, moralne, etniczne

cji wojskowo-policyjnych na terenie Małopolski Wschodniej w 1930 roku. Na przykład słynny film Wojciecha Smarzowskiego z 2016 roku Wołyń obrazów z tamtego czasu nie zawiera. Paradoksalnym przejawem niepamięci o zdarzeniach z lat 20. i 30. XX wieku stały się zajścia w Przemyślu w 2016 roku, kiedy to procesja Polaków pochodzenia ukraińskiego, której celem było uczczenie poległych żołnierzy armii Symona Petlury, walczących w 1920 roku z Rosją sowiecką u boku Piłsudskiego, została zaatakowana przez narodowców, przekonanych, że mają do czynienia z procesją, której celem jest uczczenie bojowców z Ukraińskiej Powstańczej Armii Stepana Bandery. Zob. J. Pisuliński Nie tylko Petlura: kwestia ukraińska w polityce zagranicznej w latach 1918-1923, Wydawnictwo Naukowe UMK, Toruń 2013; R. Torzecki Kwestia ukraińska w Polsce w latach 1923-1929, Wydawnictwo Literackie, Kraków 1989; T. Piotrkiewicz Kwestia ukraińska w Polsce w koncepcjach piłsudczyzny 1926-1930, Wydawnictwa UW, Warszawa 1981; R. Potocki Polityka państwa polskiego wobec zagadnienia ukraińskiego w latach 1930-1939, Instytut Europy Środkowo-Wschodniej, Lublin 2003; W. Włodarkiewicz Przed zagładą: społeczeństwo Wołynia i Małopolski Wschodniej wobec państwa polskiego (1935-1939), Muzeum Historii Polskiego Ruchu Ludowego, Warszawa 2013; W. Mędrzecki Inteligencja polska na Wołyniu w okresie międzywojennym, Wydawnictwo Neriton, Warszawa 2005; B. Stoczewska Ukraina i Ukraińcy w polskiej myśli politycznej: od końca XIX wieku do wybuchu II wojny światowej, Oficyna Wydawnicza AFM, Kraków 2013; Cz. Partacz Polska wobec ukraińskich dążeń niepodległościowych w czasie Il wojny światowej, Centrum Edukacji Europejskiej, Toruń 2003; B. Kerski, A.S. Kowalczyk Wiek ukraińsko-polski: rozmowy z Bohdanem Osadczukiem, Wydawnictwo UMCS, Lublin 2011.

2 Zob. A. Próchnik Zamach na Skałona , "Kronika Ruchu Rewolucyjnego w Polsce” 1935 nr 1; J. Krzyżanowski Sprawa Wandy Krahelskiej-Dobrodzickiej, „Wiadomości Polskie, Polityczne i Literackie" 1942 nr 38, 40, 42. Zob. także I. Pawłowski Geneza idziałalność Organizacji Spiskowo-Bojowej PPS: 1904-1905, Ossolineum, Wrocław 1976; I. Pająk Organizacje bojowe partii politycznych w Królestwie Polskim: 1904-1911, Książka i Wiedza, Warszawa 1985.

3 Chodzi o masakrę zarządzoną przez polskiego dowódcę po zdobyciu bronionej przez Rosjan twierdzy Starodub w 1535 roku. Wspomina o tym m.in. Paweł Jasienica (Polska Jagiellonów, PIW, Warszawa 1973, s. 360): „Załoga z nadzwyczajnym męstwem broniła się do ostatka, czym rozjątrzony dowódca zdobywców kazał ściąć tysiąc czterystu wziętych do niewoli żołnierzy". 
czy genderowe, trudno zatem mówić o jakimś jednolitym mechanizmie polskiego pamiętania i niepamiętania.

Jest jednak coś, co - takie jest moje przypuszczenie - stanowi strukturę bardziej podstawą.

Kluczową sprawą dla polskiej kultury - zarówno porozbiorowej, jak i obecnej - jest przeciwstawienie dwóch rozmaicie aktualizowanych, historiozoficznych matryc pamięci. Mam na myśli pamięciową matrycę narracji podmiotowej oraz pamięciową matrycę narracji podważonej czy pozornej podmiotowości. Jeśli mówić o mechanizmach selekcyjnych pamięci, to właśnie te dwie matryce odgrywają w konstytuowaniu polskiej pamięci rolę szczególną. Potrafią one funkcjonować poza sferą bezpośredniej aksjologii politycznej, łącząc w sztuce pamiętania oraz niepamiętania różne grupy Polaków, także silnie ze sobą zantagonizowane.

Matryca narracji podmiotowej akcentuje, że Polacy byli zawsze albo prawie zawsze sprawcami czy - mówiąc bardziej metaforycznie - „autorami” polskich dziejów. Moment historiotwórczego aktywizmu (indywidualnej i kolektywnej sprawczości) jest w niej wysuwany na plan pierwszy. Nawet traumatyczna świadomość klęsk, które uderzały w Polskę, nie zmienia tu podstawowego kierunku pracy pamięci, ponieważ klęski potrafi ona przeobrażać w zdarzenia zawinione, zdeterminowane przez błędne decyzje i nierozważne posunięcia, a więc przez aktywne, sprawcze działanie. $Z$ takiej perspektywy pamiętany jest przede wszystkich aspekt aktywistyczny powstań, bo nawet jeśli to były powstania przegrane, to do klęski doprowadziły nietrafne rozpoznania i postanowienia przywódców, czyli w ostatecznym rachunku decyzje samodzielnie kształtujące bieg polskiej historii ${ }^{4}$. W takim ujęciu nawet rozbiory zostały czynnie zawinione przez Polaków (formuła „Polacy sami tego chcieli”,,,sami sobie ściągnęli na głowę to nieszczęście”) ${ }^{5}$, były

4 Przykładem takich ujęć są książki stawiające kwestię, czy powstanie listopadowe mogło się udać, oraz gromadzące dowody i poszlaki, że zasadniczą przyczyną klęski były personalne błędy dowodzenia. Topos nieudolności i kunktatorstwa dowódców powstania listopadowego naszkicował już Słowacki w prologu do Kordiana, dając karykaturalny obraz przewinień "dyktatorów" Skrzyneckiego i Krukowieckiego. Eseje historyczne o podobnym wydźwięku pisałnp. J. Łojek Szanse powstania listopadowego, Instytut Wydawniczy PAX, Warszawa 1981. Zob. także Cz. Kłak Romantyczne tematy i dylematy: echa powstania listopadowego w literaturze, historiografii i publicystyce, Wydawnictwo WSP, Rzeszów 1992.

5 W takim kierunku biegły eseje i publicystyka krakowskiej szkoły historycznej. Zob. A. Wierzbicki Spory o polską duszę: z zagadnień charakterologii narodowej w historiografii polskiej XIX iXX wieku, Instytut Historii PAN, Warszawa 1993; K. Wyka Teka Stańczyka na tle historii Galicji w latach 1849-1869, Ossolineum, Wrocław 1951; J. Szujski O fałszywej historii jako mistrzyni fałszywej 
bowiem do uniknięcia, gdyby indywidualne decyzje oraz zbiorowe działania pobiegły w innym kierunku.

Ponadpolityczną formą polskiej pamięci, bazującej na pierwszej matrycy, jest idea continuum działań podmiotowych, które mają układać się w wyrazisty, spójny obraz polskich dziejów. Naczelną formułą strukturyzującą pamięć jest tu: „oddali życie, abyś ty mógł żyć godnie”, formuła, która znajduje się na Pomniku Poległych Stoczniowców w Gdańsku i odnosi się do poległych podczas zajść ulicznych w grudniu 1970 roku na Wybrzeżu ${ }^{6}$, ale rozciągana bywa na najdawniejszą przeszłość, ze szczególnym uwzględnieniem - jeśli chodzi o chwilę obecną - lat 1939-1950. To, że możemy teraz siedzieć w sali Uniwersytetu Jagiellońskiego na konferencji Pamięć polska, zawdzięczamy zatem wedle tego ujęcia - mówiąc skrótowo - głównie żołnierzom wyklętym, potem Piłsudskiemu, Kościuszce, Sobieskiemu, Jagielle, Chrobremu, a nade wszystko Mieszkowi I. Formuła ta kształtowała nie tylko nieoficjalną, niepodległościową pamięć pojałtańską, domową i opozycyjną, ale też konstruowaną (z wyjątkiem akcentowania roli Piłsudskiego) przez politykę historyczną partii komunistycznej pamięć polskiego społeczeństwa realnego socjalizmu. Budowała ona obraz polskich dziejów jako nieprzerwaną linię walki, pracy i męczeństwa, kulminującą odzyskaniem niepodległości - tu diagnoza była i pozostaje nadal przedmiotem sporów - albo w 1945, albo w 1989, albo w 2015 roku. Równocześnie wzmacniały ją słowa chyba najdziwniejszego hymnu świata, najdziwniejszego, bo w żadnym innym hymnie nie znajdziemy równie tragicznych i paradoksalnych słów: "Jeszcze naród nasz nie zginął, póki my jesteśmy przy życiu", rysujących obraz Polski jako państwa i zbiorowości co jakiś czas znajdującej się na samej krawędzi zagłady polityczno-biologicznej, której udawało się nam uniknąć cudem. Pamięć możliwej, zupełnej anihilacji i cudownych ocaleń - $z$ „cudem nad Wisłą" na czele - budowała i wciąż buduje kulturową tożsamość wielu Polaków?.

polityki: rozprawy i artykuły, PIW, Warszawa 1991; Spór o historycznq szkołę krakowską: wstulecie Katedry Historii U] 1869-1969, red. C. Bobińska, J. Wyrozumski, Wydawnictwo Literackie, Kraków 1972.

6 Zob. Miłosz. Gdańsk i okolice. Relacje, dokumenty, głosy, red. K. Chwin, S. Chwin, Wydawnictwo Tytuł, Gdańsk 2012.

7 Mam tu na myśli organizujący pamięć kilku polskich pokoleń topos „Finis Poloniae" - czyli rozmaicie aktualizowane wspomnienie chwili, w której Kościuszko podobno miał wypowiedzieć te słowa, gdy powstanie 1795 roku kończyło się ostateczną klęską. Zob. J. Tretiak Finis Poloniae!: historia legendy maciejowickiej i jej rozwiq̨zanie, Krakowska Spółka Wydawnicza, Kraków 1921. 
Równocześnie - i jest to zapewne konsekwencja trwałości i siły oddziaływania matrycy pierwszej - znaczna część Polaków trzyma się kurczowo wiary, że na przykład niepodległość po 1989 roku nie była żadnym cudem, tylko została czynnie wywalczona (wypracowana, wycierpiana), nie została zatem nam podarowana (przez los czy innych), ma więc charakter najzupełniej podmiotowy (jest efektem podmiotowego sprawstwa zbiorowości budującej swój los). Dążenie do upodmiotowienia Polski jako czynnego aktanta własnych dziejów pojawia się także w semantycznej przemianie „tych, którzy zginęli w katastrofie smoleńskiej”, w „tych, którzy polegli w Smoleńsku w służbie Ojczyzny”. I można przewidywać, że w pamięci znacznej części Polaków - może nawet w pamięci większości - pozostaną wyłącznie „ci, którzy polegli", a zupełnie przepadną bez śladu „ci, którzy stracili życie w wypadku lotniczym".

Obok tego rodzaju dominacji pamięci podmiotowej w polskiej kulturze występuje także - i tu przechodzę do funkcjonowania matrycy drugiej - przeciwstawna wobec takiego ujęcia, równoległa pamięć polskiego losu eliminująca z polskich dziejów (czy osłabiająca) element sprawczej podmiotowości.

Pamięciowa matryca podważonej podmiotowości akcentuje, że Polacy przynajmniej od czasów rozbiorów, a może i wcześniej ${ }^{8}$ - nie byli czynnymi sprawcami czy „autorami” własnych dziejów. Wedle takiego ujęcia Polska porozbiorowa nie była (i nadal nie jest) podmiotem własnej historii, lecz przedmiotem cudzych działań, któremu pozornie własne dzieje były - i są - narzucane. Powstania w takim ujęciu były działalnością czysto reaktywną, wymuszoną przez okoliczności, a nie podmiotowym czynem tworzącym historię. Rozbiory były aktem przemocy obcych wobec obezwładnionej, niezdolnej do działania Rzeczypospolitej, która utraciła zdolność kierowania własnym losem. O naszych losach decydowali inni - jawnie, skrycie, pośrednio i bezpośrednio. Wiele razy byliśmy pionkami w grze mocarstw, potęg finansowych, światowego żydostwa, przechrztów, komuny, międzynarodowego spisku masonów itd. Mesjanizm w XIX wieku szlachetną bierność Polski jako niewinnej, krzywdzonej ofiary wrogich mocy skutecznie przeobrażał w paradoksalną aktywność patriotyczno-religijnej zasługi, która w ostateczności

8 Sugestie, że Polska utraciła w znaczących stopniu swoją historiotwórczą podmiotowość już na początku XVIII wieku, formułowano otwarcie na przykład w popularnych, mających duży wpływ na nastroje w Polsce, esejach historycznych, wskazując na czasy wojny północnej i rządów dynastii Sasów jako początek tego procesu (zob. np. N. Davies Boże igrzysko, Znak, Kraków 2010). 
okazywała się czynem polskiego ducha na wskroś podmiotowym. Warta uważnego zbadania formacja duchowa pojałtańskiego pesymizmu ${ }^{9}$, nadająca w dużym stopniu ton polskiej kulturze w latach 1945-1989, akcentowała zależność linii polskich dziejów od - jak to było czasem określane - haniebnych i skutecznie ubezwłasnowolniających nas postanowień „wielkiej trójki” z Teheranu, Jałty i Poczdamu. Nie dodawała jednak do tego rodzaju rozpoznań zwykle żadnego mesjanistycznego kontekstu.

Dominacja pamięciowej narracji podmiotowej w polskiej kulturze wykracza poza polityczno-moralne konfrontacje, to znaczy poza na przykład wartościujące przeciwstawienie „romantyków” i „pozytywistów”, niepodległościowców i lojalistów czy prawicę i lewicę. Polska pamięć (zarówno prawicowa, jak centrowa czy lewicowa) broni się w różny sposób (także poprzez mechanizmy niepamiętania) przed przyjęciem do wiadomości faktu, że od początku XVIII wieku podmiotowość naszego bytu zbiorowego była stopniowo (a czasem i skokowo) skutecznie ograniczana. Polska pamięć chce pamiętać przede wszystkim o wielokrotnie ponawianych próbach odzyskiwania podmiotowości w XIX i XX wieku jako o suwerennych aktach narodowej wspólnoty, dokonywanych w sytuacji skrajnego zagrożenia. Tak właśnie w ramach tej matrycy funkcjonuje pamięć powstań. Repetycja metaforycznego obrazu z Warszawianki odgrywa tu rolę kluczową: „Powstań, Polsko, skrusz kajdany, / Dziś twój triumf albo zgon". Buduje ona spazmatyczny wizerunek polskich dziejów jako serii obrazów zamierania, grobowego letargu, konwulsyjnych przebudzeń i zmartwychwstań oraz dumnego powstawania z kolan.

Towarzyszy temu znamienne zjawisko wymazywania zdarzeń spoza paradygmatu pamięci podmiotowej. Tak tłumaczę na przykład niemal całkowite zniknięcie z polskiej pamięci najważniejszego faktu z historii Polski

9 Przez formację duchową pesymizmu pojałtańskiego rozumiem rozbudowany zbiór przypuszczeń i twardych przekonań, dochodzących do głosu w polskiej kulturze opozycyjnej i domowej (a także w polskiej literaturze) w okresie od roku 1945 prawie do końca lat 8o. XX wieku, którego skrótową, osiową formułą było: „Na sto procent komunizm nie skończy się za naszego życia”. Charakterystycznym tekstem, dowodzącym niezwykłej mocy perswazyjnej pesymizmu pojałtańskiego - silnie uwewnętrznionego przekonania o wiecznotrwałości komunizmu - stała się Mała Apokalipsa Konwickiego, dystopia, która powstała niedługo przed Sierpniem '80, ale swoim rozpoznaniem socjologicznym (apatia polskiego społeczeństwa przystosowanego do systemu) zupełnie wykluczała możliwość narodzin w Polsce takiego fenomenu jak aktywistyczny, polityczno-społeczny ruch Solidarności. Zob. S. Chwin Dlaczego upadek komunizmu zaskoczył literaturę polską, "Teksty Drugie" 1994 nr 1, s. 5-28; tegoż Literatura izdrada. Od "Konrada Wallenroda" do "Małej Apokalipsy", Oficyna Literacka, Kraków 1991. 
drugiej połowy XX wieku. Wielu Polaków bez trudu potrafi podać 4 czerwca 1989 roku, jako graniczną datę symbolizującą odzyskanie niepodległości po upadku realnego socjalizmu, mniej z nich datę podpisania gdańskich porozumień sierpniowych z 1980 roku, niewielu jednak potrafi powiedzieć, którego to dokładnie dnia ostatni żołnierz radziecki opuścił terytorium Polski. Jeśli przyjmiemy, że prawdziwe odzyskanie niepodległości polega na tym, że obca armia opuszcza teren państwa, który dotąd zajmowała, to chyba dzień całkowitego opuszczenia Polski przez Armię Czerwoną należałoby uznać za datę kluczową. Tak się jednak wcale nie dzieje.

W pamięci polskiej data odzyskania niepodległości pod koniec XX wieku jest przedmiotem sporów, żaden jednak z uczestników tych sporów nie powołuje się na nią, chociaż właśnie opuszczenie Polski przez ostatniego żołnierza obcej armii było prawdziwym początkiem polityczno-militarnej suwerenności państwa polskiego. Jak można sądzić, bierze się to być może z podświadomego przypuszczenia, że to wcale nie my, Polacy, naszą wieloletnią walką i pracą zadecydowaliśmy o tym, że Armia Czerwona wyniosła się z Polski, tylko stało się to niezależnie od nas. Można tu mówić o ścieraniu się pamięci mitycznej z pamięcią faktów. Mityczna pamięć sugeruje, że długotrwałe, powtarzające się zbiorowe, patriotyczne protesty Polaków - od straceńczej walki żołnierzy wyklętych z lat 40. po strajki gdańskich stoczniowców czy łódzkich włókniarek z końca lat 8o., nawet z pozoru bezowocne - doprowadziły w końcu do wyjazdu tysięcy radzieckich czołgów z Polski. Bardzo ważnym elementem tej mitycznej pamięci jest przekonanie, że to Jan Paweł II razem z Panną Jasnogórską zmusili (wpłynęli na, skłonili) Rosjan do wycofania głowic nuklearnych z kraju nad Wisłą. W pamięci polskiej wciąż funkcjonuje opatrywane ironicznym komentarzem stare pytanie Stalina: - A ileż to dywizji ma papież? - przywoływane jako dowód głupoty historycznych materialistów, którzy nie pojmują znaczenia czynnika metafizycznego w historii. Polska pamięć jest silnie zdominowana przez elementy światopoglądu religijnego, przede wszystkim przez topos Bożej opieki nad Polską, wedle którego szlachetne, ponawiane przez dziesięciolecia wysiłki Polaków walczących o niepodległość wspiera osobiście sam Bóg poprzez swoich ziemskich przedstawicieli i świętych orędowników ${ }^{10}$.

10 Topos ten zachowuje swoją niezwykłą trwałość w porozbiorowej kulturze polskiej, łącząc to, co polityczno-historyczne, z tym, co metafizyczne, w słynnym - zależnym od okoliczności politycznych - dwuwariantowym finale pieśni Boże coś Polskę: „Ojczyznę wolną racz nam 
Ale nawet niewierzący Polacy chętnie układają w swojej pamięci obraz przeszłości polskiej wedle matrycy kumulatywnej (formuła: wieloletnie wysiłki narodu dały rezultat). Zgodnie z nią mechanizmy niepamiętania chętnie wymazują fakt, że dziewięćdziesiąt parę procent Polaków nigdy nie było żadnymi powstańcami kościuszkowskimi, listopadowymi, styczniowymi, żadnymi powstańcami warszawskimi, żołnierzami wyklętymi czy członkami Solidarności (plakatowa liczba 10 milionów, często przywoływana jako dowód wielkiej liczebności ruchu, jest mitem kompensacyjnym, bo zapisanie się do związku wcale nie równało się byciu jego rzeczywistym członkiem, czego dowodem choćby natychmiastowy rozpad Solidarności jako ruchu masowego po 13 grudnia 1981 roku, z którego to rozpadu Solidarność już nigdy - także po roku 1989 - się nie podniosła"11).

Pamięć polska, budowana na podstawie matrycy pierwszej, jest pamięcią doświadczenia elitarnego, przedstawianego jako doświadczenie wspólnotowe, gdzie czynną działalność garstki aktantów, odmawiających zgody na polityczne status quo, chce się pamiętać jako „walkę narodu o wolność i samostanowienie". Polska pamięć, która tak ujmuje doświadczenie historyczne, jest pamięcią mniejszości podającej się za większość, ponieważ większość Polaków nie brała udziału w żadnej walce o niepodległość, tylko w kluczowych momentach dziejowych biernie wyczekiwała na ostateczne rozstrzygnięcia, by - zgodnie z uniwersalnym prawem - w większym lub mniejszym stopniu przystosować się do historycznych okoliczności, a czasem nawet mniej lub bardziej jawnie stanąć po stronie zwycięzcy. Tego rodzaju pamięć oparta na strukturze synekdochy chętnie używała - i nadal używa - generalizujących określeń typu „Polska walcząca”, „powstanie narodu polskiego”, ,Warszawa walcząca", chociaż w sierpniu 1944 roku w milionowym mieście czynnie

zwrócić Panie" oraz "Ojczyznę wolną pobłogosław Panie", gdzie w roli głównego aktanta, tworzącego polską historię, występuje Bóg jako czynna Opatrzność ingerująca - na korzyść Polaków - w dzieje powszechne. W ikonografii charakterystycznym ujęciem tego toposu stało się umieszczanie postaci Matki Boskiej i świętych na niebie ponad scenami polskich bitew (np. Bitwa pod Grunwaldem Jana Matejki czy Cud nad Wisłą Jerzego Kossaka). Teologiczno-dewocyjne wyjaśnienie "cudu nad Wisłą" jako cudu bezpośredniej Maryjnej interwencji w dzieje powszechne (osobiste zjawienie się Matki Boskiej nad Polską atakowaną przez Sowietów w 1920 roku) zob. J.M. Bartnik, E.J.P. Storożyńska Matka Boża Łaskawa a cud nad Wisłą: dzieje kultu i łaski, Wydawnictwo Sióstr Loretanek, Warszawa 2011. Zob. także M. Porębski Jana Matejki „Bitwa pod Grunwaldem", Auriga, Warszawa 1960; Jana Matejki "Bitwa pod Grunwaldem": nowe spojrzenie, red. K. Murawska-Muthesius, Muzeum Narodowe, Warszawa 2010.

11 Zob. J. Holzer, K. Leski Solidarność w podziemiu, Wydawnictwo Łódzkie, Łódź 1990, T.G. Ash Polska rewolucja: „Solidarność"1980-1982, Wydawnictwo KRĄG, Warszawa 1989. 
walczyło z Niemcami zaledwie około 10-12 tysięcy źle uzbrojonych kobiet i mężczyzn, reszta zaś próbowała przetrwać, a nawet pod koniec powstania odnosiła się do powstańców z gwałtowną niechęciąㄹ․

Dominacja pamięciowej matrycy dyskursu podmiotowego spycha na margines możliwość pamiętania historii Polski jako historii większości. Byłaby to bowiem - co matryca wyklucza - historia większości milczącej, niechętnej wszelkiemu udziałowi w polityce i aktywnym formom protestu, nastawionej przede wszystkim na rozmaite formy mniej lub bardziej biernego przetrwania w zmiennych okolicznościach trudnej polskiej historii. Historia taka musiałaby skupić się na rozmaitych mechanizmach społecznej akomodacji, których nie dałoby się zamknąć w bezpiecznej - bo dodatnio nacechowanej - formule „pracy u podstaw” czy „pracy organicznej”"13. Musiałaby ona uwzględnić także trudną pamięć o stanach społecznej anomii (np. w okresie bezpośrednio powojennym). Z takiej perspektywy historia Polski z lat 1944-1947 jawiłaby się - inaczej niż historia widziana z perspektywy mitu żołnierzy wyklętych - jako historia większości straumatyzowanej i zastraszonej, nastawionej głównie na efektywne organizowanie życia codziennego w każdych, nawet najbardziej niesprzyjających warunkach dziejowych ${ }^{14}$.

Blokada takiej pamięci łączy się w polskiej kulturze z bardzo silnym filtrem godnościowym, który procederom przystosowawczym czy postawom biernej akomodacyjnej uległości nadaje negatywną sankcję moralną i jako zjawiska godzące w dobre imię Polski i polskości odsiewa je w dyskursie wspomnieniowym jako niegodne pamiętania. Czynne działania garstki aktantów są w takim ujęciu wyolbrzymiane po to, by tym, co było statystycznie marginesowe, ale w kategoriach mitycznych doniosłe, można było przysłonić zjawiska o skali masowej, na przykład będące wyrazem społecznego konformizmu. Historia Polski jako historia milczącej większości z konieczności musiałaby akcentować pojawiające się w różnych okresach momenty społecznego rozproszenia, skutkujące w sferze symbolicznej dezintegracją obrazu spójnego

12 Świadectwa takich postaw można znaleźć już w napisanej w latach 40. książce Stanisława Podlewskiego Przemarsz przez piekło, którego rozpoznania powtórzył i rozwinął w Zdobyciu władzy Czesław Miłosz. Zob. S. Chwin Czesław Miłosz wobec powstania warszawskiego, „Teksty Drugie” $2011 \mathrm{nr}$ 5, s. 62-81.

Wchodziłaby tu w grę pamięć o społecznych - często brutalnych - strategiach przetrwania, dalekich od motywacji patriotycznej, złączonych z ryzykiem społecznej demoralizacji, tak jak je opisywał np. K. Wyka w Życiu na niby, Universitas, Kraków 2010.

14 Zob. M. Zaremba Wielka trwoga. Polska 1944-1947. Ludowa reakcja na kryzys, Znak, Kraków-Warszawa 2012. 
podmiotu zbiorowego, a dalej przekreśleniem wizji kolektywnej, wyraźnie ukierunkowanej przyszłościowo celowości działań wspólnoty narodowej jako zgodnie i konsekwentnie walczącej o niepodległość.

Matryca kumulatywna sprawia, że metaforyczny łańcuch przyczyn i skutków aktywnego działania mniejszości podającej się za większość („to my, garstka czynnych aktantów, jesteśmy prawdziwym narodem") ma charakter mityczny, bo pamięć polska - nie tylko szkolna i państwowa, lecz i domowa - chętnie buduje linię polskich dziejów wedle formuły o charakterze kumulatywnym. W ramach tego rodzaju pamięci wszystkie nawet z pozoru absurdalne polskie śmierci i druzgoczące klęski składają się na genezę finałowego - spełnionego bądź marzonego - sukcesu, chociaż nie ma między nimi a finałowym spełnieniem żadnego związku rzeczowego poza mityczno-metaforycznym, bo na przykład niezłomna walka i śmierć żołnierzy wyklętych w nader skromnym stopniu przyczyniła się do odzyskania niepodległości w 1989 roku, kiedy - jak to przedstawia matryca ograniczonej podmiotowości - na mocy postanowień „drugiej Jałty” (porozumienia między Rosją Michaiła Gorbaczowa i Stanami Zjednoczonymi Ronalda Reagana) przeprowadzono nowy podział świata na strefy wpływów i Polska ze strefy wpływów rosyjskich została „przeniesiona” do sfery wpływów amerykańskich. Rzeczywiste zasługi Solidarności i społecznych protestów z lat osiemdziesiątych XX wieku miały w tym względzie znaczenie istotne, lecz przede wszystkim pedagogiczno-symboliczne. Mimo to bardzo silną strukturą mityczną polskiej pamięci podmiotowej stała się figura przewracających się kostek domina (formuła: Zaczęło się w Gdańsku, skończyło się upadkiem muru berlińskiego, za co Europa i świat powinny być nam wdzięczne), ukazująca Polaków jako mniej lub bardziej pośrednich, ale aktywnych i skutecznych sprawców upadku imperium radzieckiego oraz wyzwolenia ludów Europy Środkowo-Wschodniej spod czerwonego panowania.

Pamięć podmiotowa jest dlatego tak mocna, że współgra ze strukturą i kalendarzem - państwowych obrzędów, w których dominuje archaiczny rys historii oglądanej z perspektywy przywódców (duchowych, politycznych, religijnych) oraz wojowników (stanowiących w każdym społeczeństwie aktywną mniejszość), a także z uniwersalną regułą pisania podręczników historii, czyli praktyczną pedagogiką patriotyzmu. W obu przypadkach nie można się obyć bez pedagogicznej fikcji czynnego aktanta. Uczciwa książka o narodzinach polskiej niepodległości po upadku realnego socjalizmu powinna nosić tytuł „Dlaczego Armia Czerwona zechciała opuścić Polskę w 1993 roku?", tymczasem znaczna część Polaków woli pamiętać, że armia 
ta została zmuszona do opuszczenia Polski wieloletnim wysiłkiem narodu, sam zaś Lech Wałęsa chętnie twierdzi, że swoim plebejsko-robotniczym sprytem wymusił to na Borysie Jelcynie, choć o ewakuacji wojsk radzieckich zadecydowały głównie globalne relacje między mocarstwami (wyścig zbrojeń, przegrana wojna w Afganistanie) i sytuacja wewnętrzna wschodniego imperium (głęboki kryzys polityczno-gospodarczy oraz erozja hierarchiczno-centralistycznego systemu sprawowania władzy).

Podobnie w przypadku uznania granicy na Odrze i Nysie w 1993 roku, które nie zostało - jak tego chce pamięć podmiotowa - czynnie wynegocjowane przez nas, tylko wymuszone na Niemcach Helmuta Kohla przez Stany Zjednoczone ${ }^{15}$. Mało kto pamięta o niepodmiotowym - czy częściowo podmiotowym - charakterze ówczesnej zmiany statusu geopolitycznego Polski. Gaśnie też pamięć, że polscy negocjatorzy na początku lat 9o. walczyli w istocie - oto prawdziwy paradoks historii - o zatwierdzenie przez zjednoczone Niemcy decyzji Stalina, który pociągnięciem czerwonego ołówka wzdłuż linii Odry i Nysy w 1943 roku wyznaczył Polakom granicę ich miejsca pobytu na Ziemi, bo to przecież nie oni wytyczyli jej przebieg w Jałcie i Poczdamie ${ }^{16}$.

Podobnie mało kto pamięta, że Gorbaczow zaczął wycofywać wojska radzieckie z Polski już w 1985 roku, nie pod naciskiem polskich protestów niepodległościowych, tylko w ramach wielkiej przebudowy, która miała uzdrowić imperium sowieckie. W drugiej połowie lat 8o. liczebność radzieckiej

Podczas panelu na Uniwersytecie Humboldta w Berlinie, poświęconego 25 rocznicy podpisania między Polską i Niemcami Traktatu odobrym sąsiedztwie, w którym brałem udział 9 września 2016 roku, były kluczowy negocjator ze strony polskiej prof. Jerzy Sułek przypomniał, że delegacja polska przez długi czas bezskutecznie usiłowała nawiązać dyplomatyczny dialog ze stroną niemiecką, traktując rozmowy jako formę negocjacji politycznych, na co delegacja niemiecka - w której zasiadał trzeci uczestnik berlińskiego panelu, Johannes Bauch - spokojnie odpowiadała, że nie uczestniczy w żadnych negocjacjach z Polską, tylko rozmawia z Polakami niezobowiązująco, ponieważ sprawa zatwierdzenia przez państwo niemieckie granicy na Odrze i Nysie może być ustalona wyłącznie na mocy traktatu pokojowego podpisanego między aliantami a Niemcami, który to traktat - co podkreślano - nie został jeszcze zawarty. Dopiero telefon Georga Busha do kanclerza Helmuta Kohla, w którym prezydent Stanów Zjednoczonych oświadczył stanowczo, że jeśli Niemcy w rokowaniach z Polakami nie zgodzą się na granicę na Odrze i Nysie, nie będzie żadnego zjednoczenia państw niemieckich, spowodował, że delegacja niemiecka radykalnie zmieniła stanowisko i traktat został szybko podpisany. Aktywistyczno-podmiotowa wersja zdarzeń zob. J. Sułek Na drodze do porozumienia i pojednania z Niemcami: wybór tekstów z lat 1989-2009, Dom Wydawniczy ELIPSA, Warszawa 2009. dawnictwo Uniwersytetu Marii Curie Skłodowskiej, Lublin 1998; K. Skubiszewski Zachodnia granica Polski w świetle traktatów, Instytut Zachodni, Poznań 1975. 
armii w Polsce zmniejszyła się z 400 tysięcy - stan bezpośrednio po wojnie - do około 70 tysięcy żołnierzy. Siedemnastego września 1993, w symboliczną rocznicę agresji radzieckiej na Polskę w 1939 roku, dowódca Północnej Grupy Wojsk generał Leonid Kowaliow zameldował prezydentowi Lechowi Wałęsie zakończenie wycofywania wojsk radzieckich z Polski. Osiemnastego września z Dworca Wschodniego wyjechała grupa ostatnich 24 oficerów, w tym 5 generałów. Ewakuacja Północnej Grupy Wojsk Armii Czerwonej do ZSRR rozpoczęła się 8 kwietnia 1991 roku. Grupa ta liczyła wówczas 53 tysiące żołnierzy oraz 7,5 tysiąca pracowników cywilnych, którym towarzyszyło 40 tysięcy członków rodzin. Jednostki radzieckie stacjonowały w 59 garnizonach w 21 ówczesnych województwach ${ }^{17}$. Wiedza o tym istnieje na dalekich marginesach aktualnej polskiej pamięci i raczej nikomu nie zależy na tym, żeby stała się ona standardowym wyposażeniem pamięci statystycznego Polaka.

Pamięć podmiotowa wymazuje też fakt, że już w latach 40. większość Polaków odwróciła się od żołnierzy wyklętych, wybierając tzw. normalne życie w realnym socjalizmie. Że to brak szerszego społecznego poparcia - które Armia Krajowa miała przez cały okres okupacji niemieckiej - był, jak to ujmował m.in. Józef Mackiewicz ${ }^{\mathbf{1 8}}$, jedną z ważniejszych przyczyn ich klęski. Sito pamięciowej matrycy dyskursu podmiotowego zapisuje tylko to, co pasuje do jego struktury, przeobrażając doświadczenie partykularne w obraz zbiorowego losu. Aktant (nieliczna grupa radykalnych niepodległościowców, gotowych walczyć do końca, stanowiąca niewielki procent ogółu społeczeństwa) staje się synekdochicznym reprezentantem urojonej całości narodu jako wspólnoty nieustępliwie walczącej o wolność.

Z pamięci polskiej stopniowo znika również obraz Kościoła uległego, zawierającego (z powodów taktycznych) 14 kwietnia 1950 roku z władzami

17 Zob. M.L. Krogulski Okupacja w imię sojuszu: Armia Radziecka 1944-1956, Wydawnictwo von Borowiecky, Warszawa 2000; tegoż Armia Radziecka w Polsce 1944-1956: dokumenty i materiały, Wydawnictwo von Borowiecky, Warszawa 2003; tegoż Armia Radziecka w Polsce 1957-1993: dokumenty i materiały, Wydawnictwo von Borowiecky, Warszawa 2002.

18 Np. w powieści Droga donikąd, gdzie pokazywał rozkład moralny polskiego społeczeństwa na terenie Wileńszczyzny zajętej przez Sowietów, który objawiał się rosnącą rezerwą (i niechęcią) społeczności lokalnych wobec nielicznych Polaków zdecydowanych prowadzić czynną walkę zbrojną z narzuconą władzą komunistyczną. Podobny obraz sytuacji społecznej żołnierzy wyklętych dał Miłosz w Zdobyciu władzy oraz Tadeusz Konwicki w Rojstach, akcentując wyobcowanie społeczne grupki byłych żołnierzy AK ukrywających się po wkroczeniu Armii Czerwonej w lasach pod Wilnem. Echa tych doświadczeń odnajdujemy także w innych książkach Konwickiego, m.in. w Senniku współczesnym. 
komunistycznymi zainicjowane przez prymasa Wyszyńskiego ugodowe porozumienie, w którym biskupi polscy zobowiązywali się karać podległych im księży za działalność niepodległościową oraz za wspieranie czynem i słowem żołnierzy wyklętych. Pamiętany jest heroizm internowanego prymasa z jego aktywnym „non possumus" (wypowiedź z 8 maja 1953 roku) ${ }^{19}$, wolimy jednak nie pamiętać o tym, jak episkopat polski zachował się po aresztowaniu kardynała we wrześniu 1953 roku, kiedy to hierarchowie publicznie odcięli się od swego eklezjalnego przywódcy ${ }^{20}$. W prawie zupełnej społecznej niepamięci utonął liczący ponad tysiąc członków ruch uległych „księży patriotów"21, przysłonięty figurami aktywistycznego patriotyzmu księdza Jerzego Popiełuszki i Jana Pawła II. Gaśnie pamięć o przedwojennych oenerowcach Bolesława Piaseckiego, współpracujących po zakończeniu II wojny światowej z komunistami w zdecydowanym tępieniu idei liberalno-demokratycznych przenikających - jak tamtym czasie to przedstawiano - do Polski z Zachodu ${ }^{22}$. Bardzo słabo pamiętana jest negatywna reakcja znacznej części polskich katolików na historiotwórczy list biskupów polskich do biskupów niemieckich z 18 listopada 1965 roku, w którym znalazły się, odczuwane wówczas jako kontrowersyjne, a nawet oburzające, skierowane do narodu niemieckiego słowa „udzielamy wybaczenia i prosimy o nie"23. Dużo bardziej wolimy pamiętać

Zob. np. J. Żaryn Prymas Wyszyński w perspektywie zmagań o niepodległość, „Biuletyn IPN” 2011 nr 10 (131).

W trosce o normalizację stosunków między Państwem a Kościołem, "Trybuna Ludu” 29 września 1953, zob. E.K. Czaczkowska KardynałWyszyński. Biografia, Znak, Kraków 2013, s. 17-22. Zdaniem Czaczkowskiej dzień wydania oświadczenia biskupów dystansujących się od postawy prymasa Wyszyńskiego po jego aresztowaniu był to "tragiczny dzień w historii episkopatu Polski". 2 listopada 1955 roku w Komańczy, gdzie przebywał internowany prymas Wyszyński, biskup Klepacz i biskup Choromański „mieli klęczeć przed prymasem, całować ręce i stopy i prosić o przebaczenie" za zdradę, jakiej mieli się dopuścić we wrześniu 1953 roku (s. 254).

Zob. A. Dudek Sutanny w służbie Peerelu, „Karta” 1998 nr 25i J. Żurek Kim byli „księża-patrioci”, "Biuletyn IPN" styczeń 2003. W roku 1952 było w Polsce około tysiąca "księży-patriotów" (co stanowiło 10-12\% wszystkich duchownych).

Zob. A. Milewski Współrządzić czy nie kłamać?: Pax i Znak w Polsce 1945-1976, Libella, Paris 1978; A. Dudek, G. Pytel Bolesław Piasecki: próba biografii politycznej, Aneks, Londyn 1990.

„Reakcja na orędzie w Polsce była jednym z najtrudniejszych okresów w okresie prymasostwa po 1956 roku. Na krótki czas władzom partyjno-państwowym udało się podkopać społeczne zaufanie do kard. Wyszyńskiego". „To była pierwsza po wojnie akcja władz przeciwko Kościołowi, w której katolicy nie stanęli wiernie przy Kościele”. Nastąpiło wówczas „autentyczne oburzenie orędziem dużej części społeczeństwa", łącznie z demonstracjami nieprzyjaznymi wobec prymasa i biskupów, do których dochodziło pod siedzibą Konferencji Episkopatu Polski 
o aktywnych działaczach opozycji antykomunistycznej, którzy w latach 70. stanowili mikroskopijny procent społeczeństwa (na przykład Komitet Obrony Robotników liczył kilkadziesiąt osób, a Ruch - największa organizacja opozycyjna - około stu, przy liczącej około $35 \mathrm{mln}$ mieszkańców populacji Polski), niż o tym, że prawie 100\% Polaków uprawnionych do głosowania co cztery lata szło ulegle do urn wyborczych, biorąc udział w socjalistycznej komedii wyborów do fikcyjnego Sejmu i fikcyjnych rad narodowych, swoją polityczno-moralną biernością legitymizując system.

Pamięciowa matryca dyskursu podmiotowego budowana była od dziesięcioleci - i w czasach zaborów, i w II Rzeczypospolitej, i w Polsce realnego socjalizmu, i po 1989 roku - jest więc bardzo stabilna i - jak się wydaje - nie zależy od zmiennej koniunktury historycznej. Pozostaje pytanie, czy matryca taka funkcjonuje z równą siłą także w kulturach pamięci innych krajów i społeczeństw o podobnej do naszej historii, czy ma zatem w pewnym zakresie charakter uniwersalny, a polska pamięć jest tylko jednym z jej wariantów. 


\section{Abstract}

\section{Stefan Chwin}

UNIVERSITY OF GDAŃSK

Polish Memory - Today: What Remains? A Lasting Trace and Mechanisms of Forgetting

A key issue for Polish culture - post-partition as well as now - is the juxtaposition of two differently actualized historiosophical matrixes of memory. The matrix of the subjective narrative stresses that the Poles have (almost) always been agents or'authors' of Polish history. This position foregrounds the moment where history is actively created through collective agency. By contrast, the matrix of the undermined subjectivity suggests that Poles - at least since the nation's partitions, but perhaps even before - have not been active agents or 'authors' of their history. These two matrixes are key to Polish memory. They are able to function beyond the sphere of immediate political axiology, and to connect, in the art of remembering and forgetting, different groups of Poles, even those that are strongly antagonistic.

\section{Keywords}

collective memory, historiosophy, subjectivity in history, synechdoche in historiography 